\title{
Non-oil economic transition for economic and environmental sustainability in Saudi Arabia: a multi-factor analysis under fuzzy environment
}

\author{
Alshehri Abdulrahman Mohammed N. ${ }^{1} \cdot$ Geng Xianhui ${ }^{1} \cdot$ Syed Ahsan Ali Shah ${ }^{2}$ (DD \\ Received: 16 March 2021 / Accepted: 3 May 2021 / Published online: 28 May 2021 \\ (C) The Author(s), under exclusive licence to Springer-Verlag GmbH Germany, part of Springer Nature 2021
}

\begin{abstract}
In this study, an analysis of Saudi Arabia's economic diversification, particularly non-oil transition, is conducted. Initially, key success factors and sub-factors that provide basis for the analysis are identified through literature survey. Three key factors (economic, labor, and market), twenty-one sub-factors (seven under each factor) are identified. To obtain the relative importance of factors and sub-factors, fuzzy analytical hierarchy process (FAHP) has been used. The economic criterion obtained the highest weight followed respectively by fiscal and labor criteria. The "proportion of Saudis in the workforce" sub-criterion received the highest weight under labor criterion, the "investment-intensive business models" sub-criterion obtained the highest weight under economic criterion, and the "increase non-oil revenue" sub-criterion got the highest weight under fiscal criterion. Overall, increase non-oil revenue sub-criterion (under fiscal criterion) received the highest weight. Later, eight major non-oil sectors are prioritized with respect to criteria and sub-criteria using fuzzy technique for order preference by similarity to the ideal solution. Petrochemicals sector ranked topped in the contribution to achieving non-oil transition. The findings of the study shall enable the government and policymakers to specifically design policies for respective sectors knowing their importance in the transition and subsequently bring a new cycle of prosperity to the Kingdom of Saudi Arabia.
\end{abstract}

Keywords Non-oil transition $\cdot$ Economic diversification $\cdot$ Multi-criteria decision analysis $\cdot$ Fuzzy analysis $\cdot$ Saudi Arabia

\section{Introduction}

Saudi Arabia has remained an oil giant, whose economy relies mainly on oil exports. Oil products constitute $90 \%$ of kingdom's export. This single resource dependence has raised many concerns on numerous occasions. For instance, during

Responsible Editor: Philippe Garrigues

Geng Xianhui

ngxh@njau.edu.cn

Syed Ahsan Ali Shah

ahsan.shah1@hotmail.com

Alshehri Abdulrahman Mohammed N.

abulrahmanm@yahoo.com

1 College of Economics and Management, Nanjing Agricultural University, No. 1 Weigang, Nanjing, 210095, Jiangsu, People's Republic of China

2 School of Economics and Management, Nanjing University of Science and Technology, Nanjing, 210094, People's Republic of China economic recession or oil price shocks in the international markets, Saudi Arabia finds itself in a hard position. The oil prices are influenced by numerous economic and geopolitical factors which most of the time are beyond the control of oil producing countries. The other concern is the increasingly exhausting oil resources that, according to an estimate, shall be run off by 2050 if consumed on current pace (Shah and Solangi 2019). Nonetheless, the major setback to oil consumption comes from renewable energy sources that are now competitive enough to replace oil. Also, switching to renewable energy sources is inevitable for attaining goal of Paris Agreement that is to limit $\mathrm{CO}_{2}$ emission below $1.5^{\circ} \mathrm{C}$ to mitigate climate change - a massive threat to the world (Shah et al. 2019b). Consequently, the future of oil is bleak and the kingdom is well aware of this fact.

The oil related threat is an external challenge. However, the kingdom is also faced with an internal challenge that poses a potential threat for the country to handle. This challenge is of demographics and the estimated number of Saudi labor force. More than half of Saudi Arabia's population is under 25, and by 2030, the number of Saudis aged 15 and over may increase by 
about 6 million. Based on the historical trend of participation, it is estimated that this forthcoming expansion of population will bring nearly 4.5 million new working-age Saudi nationals into the workforce by 2030. If accompanied by a higher-thanexpected increase in the female labor force participation rate, this number will be even higher. To absorb this influx, it will be necessary to create jobs for Saudi Arabia that are almost three times the jobs created by the kingdom during the 2003-2013 oil boom (Bokhari 2020). The number of elderly people supported shall also increase, which shall burden the kingdom's health and finance system (Albassam 2015).

Together, the internal and external challenges have a major impact on the kingdom's current development model and its financial stability (Emara et al. 2019). The government has very large fiscal reserve assets, twice the size of Russia's reserve currency (in US dollars). Besides these reserves, its assets far exceed 1.4 trillion US dollars, including a large number of state-owned companies whose publicly listed stocks currently account for one third of the total value of the national stock market. Even so, lack of action can cause huge losses to the economy and the government. For each year of delay, it is estimated that by 2030, the government's additional costs for higher operating costs and reduced oil revenues will be approximately 190 billion Saudi Riyals (SAR), or 50 billion US dollars. In other words, it can increase the Saudi government's break-even oil price by US\$18 per barrel in 2030 (Alawi 2019). Without more comprehensive reforms, the Kingdom of Saudi Arabia may accumulate net debt of about $140 \%$ of GDP in 2030, and it may still have a huge fiscal deficit. Even after assuming that public spending is nominally frozen at today's levels in 2020, this not only means further growth, but a real decline in 2030, with public spending falling from $40 \%$ of GDP in 2014 to nearly $30 \%$ in 2030 (Iradian 2019).

The kingdom has learned the fact that the current path of dependence on oil revenues cannot be maintained for longer (Topal 2019) and that it should build a vibrant twenty-first century economy. Consequently, the kingdom launched "Saudi Vision 2030" aiming to expand non-oil economic sectors for economic development and jobs creation. This transition to non-oil sectors shall allow more economic flexibility to the kingdom in the future and shall diversify its economic resources (Vietor and Sheldahl-Thomason 2018).

The non-oil sectors of Saudi Arabia have developed strongly. An increase in in private sector' activities enlarged the share of non-oil economic activities by about $10 \%$ of GDP between 2004 and 2018. Nonetheless, a wholly transition from oil to non-oil economy is not an easy task to achieve. Saudi Arabia should move from government-led economic and social model to a more market-based way to adjust it to other modern-day economies. It requires making necessary changes and reforms to realize this goal. The government is seemed accelerating its efforts keenly in the recent past. However, to make right moves, the scientific community should also align their efforts with Saudi government, and research and analyze factors and findings that can help the government to achieve this objective. Achieving non-oil transition does not only benefit Saudi Arabia but whole world in a sense that the curbing of oil consumption shall substantially help in limiting carbon emission.

Subsequently, this study is conducted to provide useful insight and inclusive analysis of the kingdom's transition towards non-oil sectors. As such, no study can be found in the existing literature that is useful and provides analysis of similar fashion. The contribution of this study is manifold. For instance, this study does not only find key success factors (vital for transition) from the literature but also analyzes them and computes their relative importance. Furthermore, it presents the key details and roles of non-oil sectors in non-oil transition. It also performs a comparative analysis of these sectors with respect to their contribution towards the ultimate transition and achieving "Saudi Vision 2030." The study ranks the sectors based on their performance in fulfilling critical success factors important for the transition. The ranking shall enable the government and policymakers to introduce specific policies and reforms for low-ranking sectors instead of implementing generic ones.

The rest of the study proceeds followingly: the "Literature survey" section presents literature survey in which critical success factors are identified and a brief overview of non-oil economic sectors is given. The "Proposed research framework" section introduces to the proposed integrated framework, gives background of methods applied, and provides methodological steps taken for the analysis. The "Results and analysis" section comprises analysis and results. The "Discussion" section discusses the overall study and its outcome. Finally, the "Conclusion" section provides the conclusion of the study and puts forward some key implications.

\section{Literature survey}

\section{Identification and selection of critical success factors}

The critical success factors identified through literature survey and experts' feedback are provided in Table 1. Three major factors have been identified including labor, economic, and fiscal. Under each main factor, seven sub-factors have been selected; a brief description of these sub-factors is also provided in Table 1.

\section{Overview of major non-oil sectors}

In this study, eight most important non-oil sectors given in Fig. 1 have been selected for performance investigation. 
Table 1 List of critical success factors and sub-factors

\begin{tabular}{|c|c|c|c|}
\hline $\begin{array}{l}\text { Success } \\
\text { factors }\end{array}$ & Sub-factors & Code & Reference \\
\hline \multirow[t]{7}{*}{ Labor factors } & Labor participation & L-1 & (Alam 2009; Banafea and Ibnrubbian 2018; Zhu et al. 2018; Snudden 2019) \\
\hline & Labor market flexibility & L-2 & $\begin{array}{l}\text { (Alam 2009; Callen et al. 2014; Mahroum and Al-Saleh 2016; Bokhari 2017; He } \\
\text { et al. 2018a) }\end{array}$ \\
\hline & Foreign labor & L-3 & $\begin{array}{l}\text { (Alam 2009; Ramady 2010; Alhamad 2014; Banafea and Ibnrubbian 2018; He } \\
\text { et al. 2020) }\end{array}$ \\
\hline & Proportion of Saudis in the workforce & L-4 & (Sohail 2012; Al-Asfour and Khan 2014; Alkhathlan et al. 2020) \\
\hline & Proportion of Saudi women in the workforce & L-5 & (Sohail 2012; Varshney 2019; Alkhathlan et al. 2020) \\
\hline & Wage levels & L-6 & (Sohail 2012; Alhamad 2014; Callen et al. 2014) \\
\hline & Skilled Saudi workers & L-7 & (Madhi and Barrientos 2003; Sohail 2012; Al-Sarihi 2019) \\
\hline \multirow[t]{7}{*}{$\begin{array}{l}\text { Economic } \\
\text { factors }\end{array}$} & Supportive business environment & E-1 & $\begin{array}{l}\text { (Thompson et al. 2012; Mahroum and Al-Saleh 2016; Banafea and Ibnrubbian } \\
\text { 2018; Al-Sarihi 2019) }\end{array}$ \\
\hline & More competition & E-2 & (Thompson et al. 2012; Callen et al. 2014; He et al. 2018b; Park et al. 2019) \\
\hline & Improved infrastructure & E-3 & $\begin{array}{l}\text { (Alam 2009; Zuo et al. 2015; Al-Sarihi 2019; Trigunarsyah et al. 2019; Chen } \\
\text { et al. 2021) }\end{array}$ \\
\hline & Investment-intensive business models & E-4 & (Ramady 2010; Bokhari 2017; Al-Sarihi 2019) \\
\hline & Professionalized management practices & E-5 & $\begin{array}{l}\text { (Rehman et al.; Thompson et al. 2012; Mahroum and Al-Saleh 2016; Khojah } \\
\text { 2018) }\end{array}$ \\
\hline & Level of Foreign Direct Investment & E-6 & $\begin{array}{l}\text { (Kadi; Ramady 2010; Banafea and Ibnrubbian 2018; Belloumi and Alshehry } \\
\text { 2018) }\end{array}$ \\
\hline & Level of local private investment & E-7 & (Alam 2009; Thompson et al. 2012; Biygautane et al. 2018; Younis et al. 2021) \\
\hline \multirow[t]{7}{*}{ Fiscal Factors } & Increase non-oil revenue & F-1 & $\begin{array}{l}\text { (Ramady 2010; Banafea and Ibnrubbian 2018; Al-Sarihi 2019; Hussain and } \\
\text { Rehman 2021) }\end{array}$ \\
\hline & Government share of investment & $\mathrm{F}-2$ & (Thompson et al. 2012; Callen et al. 2014; Moshashai et al. 2020) \\
\hline & Returns from state-owned assets & F-3 & $\begin{array}{l}\text { (Alam 2009; Callen et al. 2014; Mahroum and Al-Saleh 2016; Shah and } \\
\text { Longsheng 2020) }\end{array}$ \\
\hline & Energy market price reforms & $\mathrm{F}-4$ & (Sohail 2012; Al-Sarihi 2019; Rehman et al. 2019; Aldubyan and Gasim 2020) \\
\hline & $\begin{array}{l}\text { Proportion of capital expenditure savings in } \\
\text { government expenditure }\end{array}$ & F-5 & (Callen et al. 2014; Bokhari 2017; El-Awady et al. 2020; Ahmad et al. 2020b) \\
\hline & Support financing of government deficit & F-6 & (Al-Qudair 2005; Mahroum and Al-Saleh 2016; Banafea and Ibnrubbian 2018) \\
\hline & Reduce fiscal gap & F-7 & (Alam 2009; Ramady 2010; Bokhari 2017; Ahmad et al. 2020a) \\
\hline
\end{tabular}

These sectors include mining and metals, tourism and hospitality, petrochemicals, manufacturing, finance, construction, retail and wholesale trade, and healthcare. The brief introduction of these sectors including their significance is given in following sub-sections.

\section{Mining and metals (S-1)}

Over the past few years, Saudi Arabia's mining and metals industry sector has achieved a remarkable growth. As inscribed in the "Saudi Vision 2030," the kingdom intends to exploit this sector to maximize the potential of the national economy and create massive growth opportunities. Saudi Arabia's proximity to other Middle East and North Africa countries/regions puts local manufacturers in a good position to export to these countries. The huge demand, coupled with Saudi Arabia's rich soil resources, has created important investment opportunities for private sector investors. Therefore, the industrial cluster and its strategic partners are working hard to expand the main raw material industry and develop sustainable, globally competitive value-added semi-finished and finished metal industries to support the Kingdom's goal of diversification and development of advanced industries.

\section{Tourism and hospitality (S-2)}

Tourism and hospitality sector is the second largest non-oil contributor to the Kingdom's GDP. According to data from

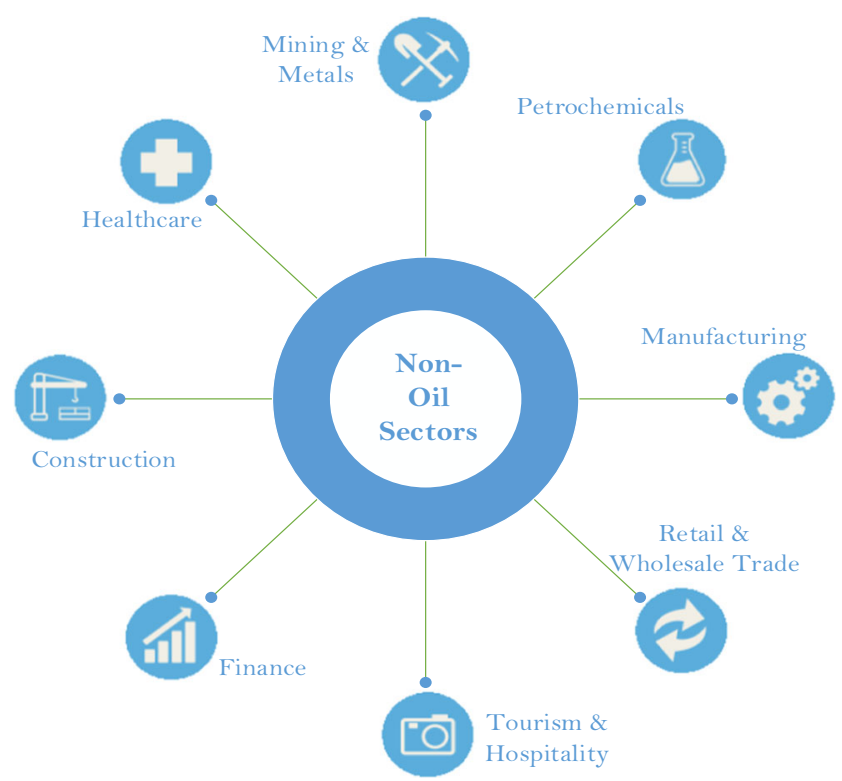

Fig. 1 Key non-oil sectors in Saudi Arabia 
Fig. 2 Integrated research framework

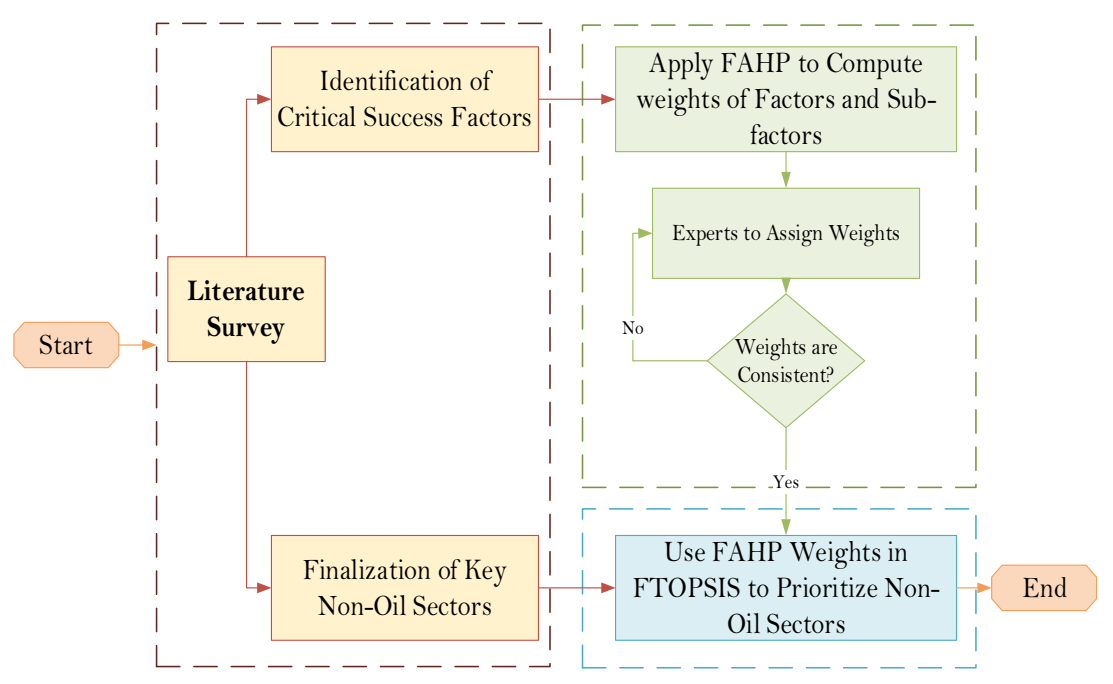

the World Travel and Tourism Council, the GDP of Saudi Arabia in 2017 was estimated at 240.9 billion Rials, accounting for $9.4 \%$ of GDP. The Saudi Arabian government's investment in the hospitality industry and tourism is driving the rapid growth of the industry. According to the report of TRI Consulting, the value of the industry is expected to grow to 400 billion Saudi Arabian Rials (it will reach 107 billion US dollars by 2028). These figures are presented in the "Saudi Vision 2030" economic diversification agenda, which aims to promote government-led tourism projects that the report claims will support the Kingdom's envisioned post-oil economy.

\section{Petrochemicals (S-3)}

The petrochemical industry is one of the primary non-oil sectors in Saudi Arabia. Regarding value, Saudi Arabia's plastic and chemical exports added up to 30 billion US dollars (115 billion Rials) in 2015, representing $60 \%$ of absolute non-oil trades. The Saudi petrochemical industry has developed from a neighborhood industry to one of the principle mainstays of the Saudi economy, and this fast development has brought forth a portion of the world's biggest and most profitable companies. Taking into account that this change occurred in a brief timeframe, the ascent of the Saudi petrochemical industry is much more remarkable.

Looking forward, the initiation of the "National Transformation Plan 2020" and "Saudi Vision 2030" will help advance growth opportunities in the business through technological innovation and infrastructural enhancement. The government is putting vigorously in the industry, increasing investors' interest and supporting Saudi foreign joint-ventures for new petrochemical projects. In the end, the sustainable development of the sector can in reality be accomplished by going down its value chain, that presently begins to occur in the country.

\section{Manufacturing (S-4)}

Saudi Arabia is the fastest-growing country in the manufacturing industry, and by 2018 , the average annual growth rate is expected to be $7.5 \%$. Saudi Arabia's manufacturing industry is expected to achieve significant growth especially in the technical field on regional as well as global scale. The Saudi Arabian government has given huge administrative and monetary help to the manufacturing sector. Few such examples are as follows: developing necessary infrastructure, establishing of new modern cities Jubail and Yanbu, founding Saudi Industrial Development Fund, and offering different other incentives to add to industrialization.

The government currently plans to invest nearly 70 billion US dollars to build six new economic cities with commercial support regulations and modern infrastructure. Their presence in the plastics and chemical markets makes their plans easy to implement. The recent oil price collapse has shifted the focus to other sectors, and the manufacturing sector ranks first in terms of potential and financial support. Facts have proved that this is a blessing in disguise for Saudi Arabia, because it will provide future options for their oil-dependent economy. The support of the government, the promotion of massive investment in manufacturing and the welcome of foreign direct investment have brought opportunities for this sector in Saudi Arabia.

\section{Finance (S-5)}

The Saudi Arabian Monetary Authority (SAMA) was set up in 1952 as the focal financial and banking authority of Saudi Arabia. It supervises business and development banks and other monetary institutions. Its prime duties include giving, controlling and balancing out the value of the country's currency Rial; acting as a national banker; and overseeing foreign exchange investment and reserves. Since it is an Islamic 
Table 2 Fuzzy scale

\begin{tabular}{lll}
\hline Fuzzy number & Linguistic variables & Membership function \\
\hline$\widetilde{1}$ & Preferred-equally & $(1,1,1)$ \\
$\widetilde{3}$ & Preferred-moderately & $(2 / 3,1,3 / 2)$ \\
$\widetilde{5}$ & Preferred-strongly & $(3 / 2,2,5 / 2)$ \\
$\widetilde{7}$ & Preferred-very strongly & $(5 / 2,3,7 / 2)$ \\
$\widetilde{9}$ & Preferred-extremely & $(7 / 2,4,9 / 2)$ \\
\hline
\end{tabular}

institution, it operates on a non-profit status. As per Islamic law, banks do not charge interest, however, banks charge fees on borrowings and commissions on deposits. Albeit the government is progressively disposed to grow the private sector, the money supply and the speed of business are overwhelmed by government' economic activities.

There are numerous commercial banks in the country, some of which are joint-ventures between Saudi residents and foreign banks. Similar to all other organizations, foreign banks likewise cannot function in the country without Saudi accomplices. For local banks, Saudis own them all. Customarily, banking regulations have not been stringently authorized, and private banks have shown extraordinary adaptability and creativity in deciphering Islamic financial guidelines. Furthermore, notwithstanding the omnipresence of banks in the country, an enormous number of residents and foreigners actually depend on money changers to facilitate and provide anonymous services.

\section{Construction (S-6)}

The Saudi Contractors Authority was established in 2017 and is the main agency responsible for overseeing the construction industry in the Kingdom of Saudi Arabia. According to data released by the National Bureau of Statistics, the construction industry contributed approximately 163 billion riyals $(\$ 43.5$ billion) to the national economy in 2019, accounting for 5.5\% of GDP and $7.3 \%$ of non-oil GDP. The industry actually grew by $4.6 \%$ in 2019 , exceeding the overall non-oil GDP growth rate of $3.3 \%$. This is a significant improvement compared to previous years. The industry shrank by $3.2 \%$ in $2016,3.3 \%$ in 2017, and $3.5 \%$ in 2018 .

Under the guidance of "Saudi Vision 2030," the construction industry is expected to achieve significant growth in the next ten years. Construction activities accelerated in 2019,

Table 3 Random index values

\begin{tabular}{lllllllll}
\hline $\boldsymbol{n}$ & 1 & 2 & 3 & 4 & 5 & 6 & 7 & 8 \\
\hline $\boldsymbol{R I}$ & 0 & 0 & 0.52 & 0.89 & 1.11 & 1.25 & 1.35 & 1.40 \\
\hline
\end{tabular}

with many infrastructure plans announced and launched. In addition, some large-scale projects such as the Riyadh Metro station are nearing completion, and mega-projects that are emerging in the Kingdom of Saudi Arabia are driving optimism in the industry and related industries. Although the long-term outlook remains optimistic, the Covid-19 crisis led to a slowdown in the entire economy in 2020 .

\section{Retail and wholesale trade (S-7)}

The retail industry in Saudi Arabia may flourish as online retail. The modern forms will replace the traditional "corner" stores in the Baccarat community. Overall, we gauge that retail and wholesale trade can possibly employ nearly 800,000 Saudi nationals in the following 15 years, and its additional worth will significantly increase. Driven by the increase in household income, the retail industry has grown rapidly at a rate of $12 \%$ per year in the past decade. Although the workforce is now mainly composed of low-paid foreign workers, the number of Saudi Arabians working in the industry has increased enormously. This is especially the sector where Saudi women find jobs. This reflects the government's efforts to encourage the "spreading" and feminization of retail categories targeted at women (such as underwear or cosmetics). Adapting to modern retail formats, rapid online migration and adoption of best retail practices (including improving supply chain efficiency, such as increasing the degree of warehouse automation) can significantly increase productivity and growth.

\section{Healthcare (S-8)}

Saudi Arabia will need to continue to spend on healthcare heavily, especially given that the number of Saudis over 65 years old is expected to increase by 2030. Saudi Arabia faces three major challenges, but also brings opportunities: the current low productivity and the possibility of increasing financing activities in the private sector; the structure of the health care workforce, whose structure cannot address increase of non-communicable diseases such as diabetes. Also, demand for health professionals and workers has increased. At present,

Table 4 Linguistic variables scale (Han and Trimi 2018) 
only one tenth of the 10 executive summary nursing staff of the McKinsey Global Institute of health care institutions are Saudi nationals. In order to reverse this trend, some measures will be needed to increase people's awareness of the health care profession and improve the educational capacity of universities, and appropriately equipped teaching hospitals.

\section{Proposed research framework}

The schematic of the proposed research framework is given in Fig. 2. Initially, a thorough literature survey was conducted to identify key factors that can help smooth the drive of Saudi Arabia to become a non-oil economy. Later, major non-oil sectors vital for non-oil transition were sorted out. After that, twenty experts, local and international, were engaged for their opinion related to the analysis. The selection of experts was made according to their experience and knowledge regarding the topic. Finally, two most prominent approaches of MCDM were applied to process the experts' opinion and obtain the results. For instance, FAHP was employed to obtain the relative importance of factors and subfactors by computing their crisp weights. And, FTOPSIS was applied to rank the alternative sectors based on their performance in the implementation of critical success factors.

\section{Materials and methods}

\section{Fuzzy set theory}

For real-world issues, it is difficult to get exact information for indicator estimation. Decision-makers regularly utilize common language expressions rather than numeric values while assessing the issues (Jiskani et al. 2020). The utilizations of the fuzzy theory end up being best in obscure and vague circumstances. It translates human decisions and judgements into information which is then used in decision-making analysis (Musaad et al. 2020a, b). The fuzzy theory was presented by Zadeh in 1965 . The theory can proficiently translate dubious information into crisp data that can be valuable. It includes fuzzy sets, fuzzy numbers and membership function (Zadeh 1978). It manages group data whose limits are not characterized. One of the principle benefits of utilizing fuzzy theory is that it shows the meaning of criteria and choices with fuzzy numbers instead of utilizing crisps numbers in light of the fact that the decision-making in real world faces circumstances where explicit information and sequence of potential options are not known. The fuzzy theory utilizes trapezoidal fuzzy numbers (TFNs) to deal with the vagueness of parameters for options determination. Rather than crisp numbers, boundaries signify TFN for expressing the fuzziness in the development of pairwise matrices or the decision-making (Shah et al. 2021).

Thus, TFNs are applied in this study. TFN presents as $R_{i j}=\left(x_{i j}, y_{i j}, z_{i j}\right)$; where $y_{i j}$ is median of fuzzy number $R_{i j}$; while $x_{i j}$ are left and right sides of fuzzy number $R_{i j}$, subsequently. Suppose two TFNs, i.e., $R_{1}$ and $R_{2}$, where $R_{1}=\left(x_{1}, y_{1}, z_{1}\right)$ and $R_{2}=\left(x_{2}, y_{2}, z_{2}\right)$, then mathematical operations on them can performed as below (Musaad et al. 2020a, b):

$$
\begin{aligned}
& \left(x_{1}+x_{2}, y_{1}+y_{2}, z_{1}+z_{2}\right)=\left(x_{1}, y_{1}, z_{1}\right) \oplus\left(x_{2}, y_{2}, z_{2}\right) \\
& \left(x_{1} \times x_{2}, y_{1} \times y_{2}, z_{1} \times z_{2}\right)=\left(x_{1}, y_{1}, z_{1}\right) \otimes\left(x_{2}, y_{2}, z_{2}\right) \\
& \left(1 / z_{1}, 1 / y_{1}, 1 / x_{1}\right)=\left(x_{1}, y_{1}, z_{1}\right)^{-1}
\end{aligned}
$$

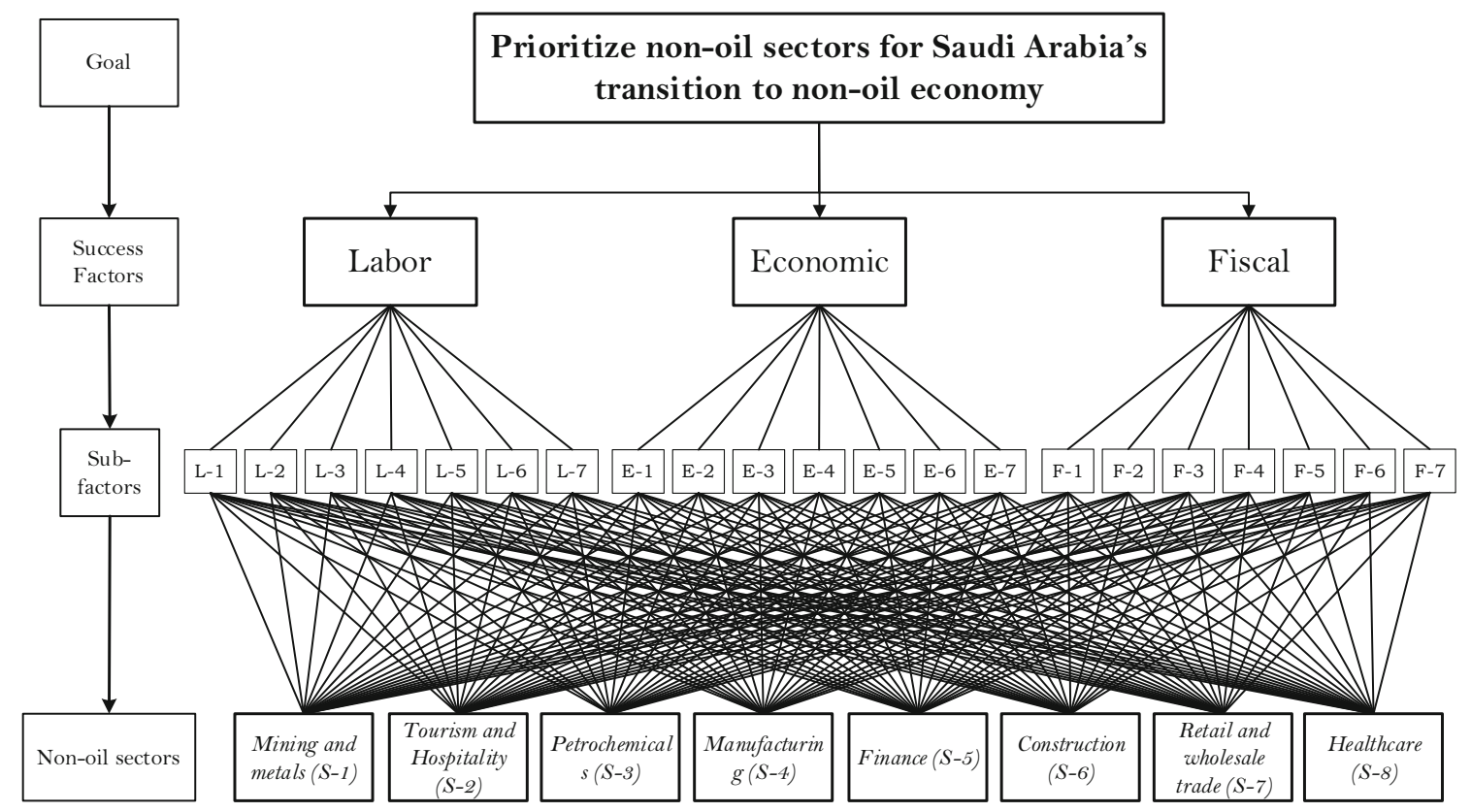

Fig. 3 Hierarchical structure 
Fig. 4 Main criteria weights

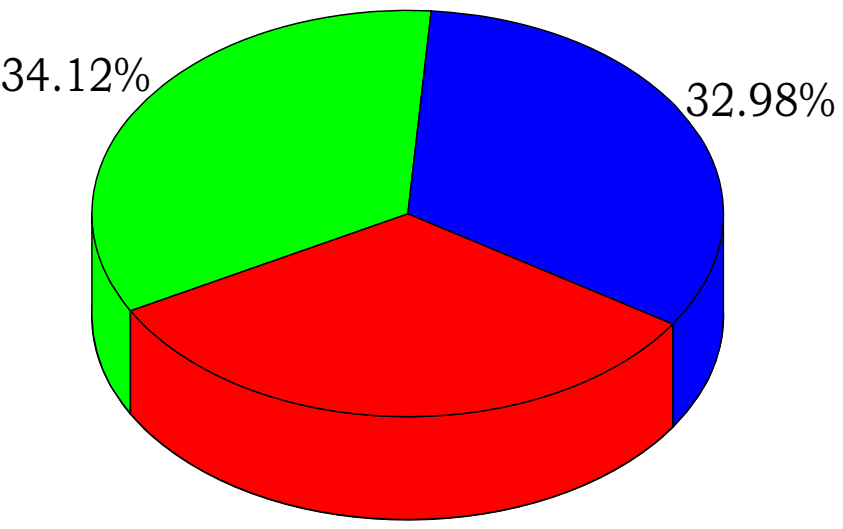

$32.89 \%$

\section{Labor Factor $\square$ Economic Factor $\square$ Fiscal Factor}

\section{FAHP}

The AHP method was proposed by Saaty. It is quite possibly the most generally utilized MCDM model to settle intricate and multifaceted decision-making issues. AHP is utilized to evaluate DM's general needs for a bunch of choices on a proportion scale (Jiskani et al. 2020). This model underscores the significance of DM's natural decisions and consistency of looking at options during the decision-making cycle (Jiskani et al. 2021). Despite the fact that AHP can be applied to evaluate decision makers' judgment, notwithstanding, the technique still has flaws in accurately translating the human perspective. Hence, Saaty's AHP was advanced into FAHP, which is widely utilized and all the more remarkable procedure to translate vagueness and indistinctness associated with DM's perspective (Muhammad et al. 2020). The FAHP consolidates conventional AHP with the fuzzy set theory in which DM's opinion is characterized by a membership function (Shah 2019).

In the first step, FAHP builds up a hierarchal representation of the issue. The structure includes goal to be achieved, criteria, and sub-criteria. The next step builds pairwise comparison matrices to compare segments according to their significance and relevance to goal, criteria, and sub-criteria. Afterward, TFNs are utilized to characterize relative significance to incorporate impression in human judgment. In this study, five TFNs such as $(\tilde{1}, \widetilde{3}, \widetilde{5}, \widetilde{7}, \widetilde{9})$ are used in which $\tilde{1}$ represent equal preference among the elements and $\widetilde{9}$

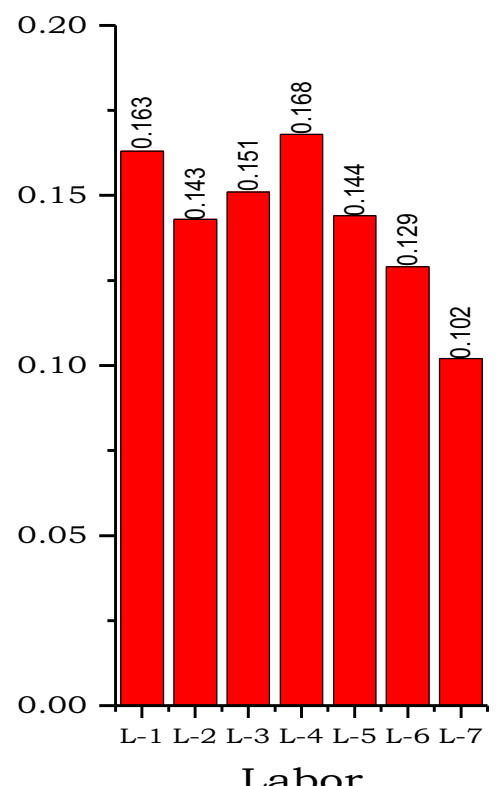

Labor

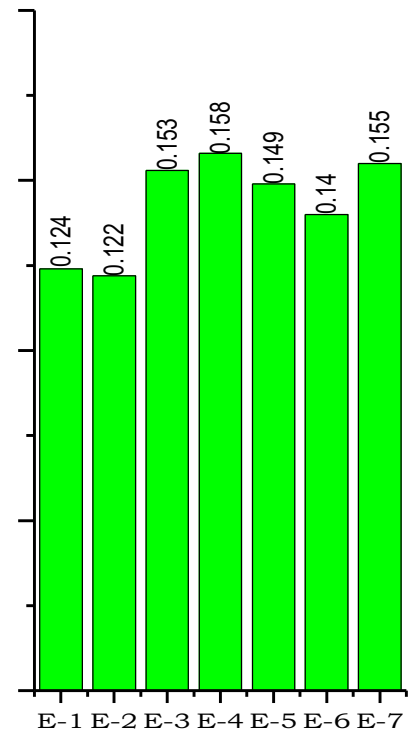

Economic

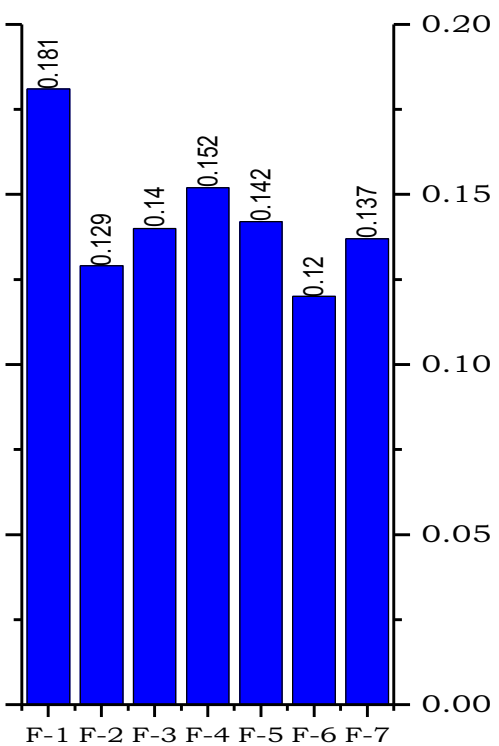

Fiscal

Fig. 5 Weights of sub-criteria under criteria 
translates that there is extreme preference among the elements. Further detail on linguistic values and membership function of TFNs is provided in Table 3. For inverse comparisons, reciprocal values shall be taken. For instance, $a_{j i}=\frac{1}{a_{i j}}$ is an inverse comparison, where $a_{i j}$ depicts importance of $i t h$ component on jth component (Table 2). Accordingly, a fuzzy matrix $\widetilde{\mathrm{A}}$ is developed as:

$\widetilde{A}=\left[\begin{array}{cccc}1 & \widetilde{a}_{12} & \ldots & \widetilde{a}_{1 n} \\ \widetilde{a}_{21} & \cdot & . & \cdot \\ \vdots & \cdot & \cdot & \cdot \\ \widetilde{a}_{n 1} & \widetilde{a}_{n 2} & \ldots & 1\end{array}\right]$

In the third step, aggregation of singular judgment is undertaken group priority vectors are produced. Studies show two regular methodologies for judgements aggregation. These methodologies are as follows: "aggregating individual priorities" (AIP), and "aggregating individual judgements" (AIJ). The previous is relevant in a circumstance where individuals act all together while the last is appropriate in a circumstance where individuals act independently (Forman and Peniwati 1998). This study utilizes AIJ technique to aggregate individual decisions in light of the fact that this technique handles experts' decisions at prior stages and evades from any re-assessments by experts required if irregularities emerge at later phase of alternative rankings (Table 3). Let the TFN scores given by expert $i$ to component $j$ represent as $\widetilde{w}_{i j}=\left(a_{i j}, b_{i j}, c_{i j}\right)$; where $(i=1,2, \ldots, n)$ and $(j=1,2, \ldots$, $m)$. The aggregate judgement $\widetilde{w}_{i j}=\left(a_{i}, b_{i}, c_{i}\right)$ where $(j=1,2$, . . , $m)$ of a group is given by $a_{j}=\operatorname{Min}_{i}\left\{a_{i j}\right\}, b_{j}=\frac{1}{n} \sum_{i=1}^{n} b_{i j}$, and $c_{j}=\operatorname{Max}_{i}\left\{c_{i j}\right\} . \quad \mathrm{T} \mathrm{h} \mathrm{e}$ crisp value of TFN $\widetilde{w}_{i j}=\left(a_{i}, b_{i}, c_{i}\right)$ where $(j=1,2, \ldots, m)$ is obtained by $w_{j}=\left[a_{j}+\left(4 \times b_{j}\right) \frac{+c_{j}}{6]}\right.$.

In the later step, consistency check of pairwise comparisons shall be performed. For doing so, consistency index $C I=\left(\lambda_{\max }-n\right) /(n-1)$ is used in which $n$ shows the size of the matrix. The consistency of judgement is checked using consistency ratio $C R=C I / R I$ where $R I$ denotes random consistency index whose values are listed in Table 4 . The judgment matrix is acknowledged if the estimation of $\mathrm{CR}$ is more or equivalent to 0.1 ; otherwise it is considered as unacceptable (Xu et al. 2019a).

\section{FTOPSIS}

TOPSIS is another broadly utilized MCDM strategy to tackle decision-making problems in an assortment of fields. TOPSIS is a direct weighting method proposed by (Lai et al. 1994). TOPSIS picks an alternative that has the longest separation from a negative ideal solution and the briefest separation from a positive ideal solution. According to TOPSIS, the best alternative has greater comparability to the positive ideal solution (Solangi et al. 2021). The conventional TOPSIS approach utilizes crisp numbers to allot singular inclinations. Notwithstanding, actually, it frequently turns out to be hard for a DM to allocate an exact execution score. Thus, there remains always a portion of vagueness in DM's judgment (Xu et al. 2019b). To counter this lacking, fuzzy set theory is integrated with TOPSIS. Subsequently, a fuzzy-based TOPSIS strategy has been utilized to acquire more dependable outcomes by limiting the probability of uncertainty. Following steps of FTOPSIS have been executed in this study:

Step 1. Define a linguistic variable scale. This study adopted fuzzy linguistic scale provided in Table 1.

Step 2. Let $\widetilde{A}=\left(a_{1}, a_{2}, a_{3}\right), \widetilde{B}=\left(b_{1}, b_{2}, b_{3}\right)$ are the two fuzzy numbers; thus, their mathematical relation is as follows:

$\widetilde{A}+\widetilde{B}=\left(a_{1}+b_{1}, a_{2}+b_{2}, a_{3}+b_{3}\right)$

$\widetilde{A} \times \widetilde{B}=\left(a_{1} b_{1}, a_{2} b_{2}, a_{3} b_{3}\right)$

Step 3. Let $\widetilde{A}_{i}=\left(a_{i 1}, a_{i 2}, a_{i 3}\right)$ be a TFNs for $i \in I$. Later, the normalized fuzzy number of each $\widetilde{A}_{i}$ is shown as (Jiskani et al. 2021):

$\widetilde{R}=\left[r_{i j}\right]_{m \times n}$

where $i=1,2,3, \ldots, m$ and $j=1,2,3, \ldots, n$

For a positive ideal solution (benefit criteria), the fuzzy normalization process is presented as:

$r_{i j}=\left(\frac{a_{1 i j}}{a_{3 j}^{*}}, \frac{a_{2 i j}}{a_{3 j}^{*}}, \frac{a_{3 i j}}{a_{3 j}^{*}}\right)$

where $a_{3 j}^{*}=\max a_{3 i j}$ is a benefit-type criterion.

For negative ideal solution (cost criteria), the fuzzy normalization process is shown as:

$r_{i j}=\left(\frac{a_{1 j}^{-}}{a_{3 i j}}, \frac{a_{1 j}^{-}}{a_{2 i j}}, \frac{a_{1 j}^{-}}{a_{1 i j}}\right)$

$a_{1 j}^{-}=\min a_{1 i j}$ is cost type criterion.

Step 4. Construct the fuzzy weighted normalized decision matrix. 


$$
\begin{aligned}
& \widetilde{V}=\left[v_{i j}\right]_{m \times n} \\
& \quad i=1,2,3, \ldots, m \text { and } j=1,2,3, \ldots, n \\
& \quad \text { Here, } v_{i j}=r_{i j} \times w_{j}
\end{aligned}
$$

Step 5. Determine the distance between fuzzy ideal $\left(d_{i}^{+}\right)$ and fuzzy negative $\left(d_{i}^{-}\right)$the ideal solution.

$d_{i}^{*}=\left(v_{1}^{*}, v_{2}^{*}, v_{3}^{*}, \ldots, v_{n}^{*}\right)$

where $V_{j}^{*}=(1,1,1) j=1,2,3, \ldots, n$

$d_{i}^{-}=\left(v_{1}^{-}, v_{2}^{-}, v_{3}^{-}, \ldots, v_{n}^{-}\right)$

where $V_{j}^{-}=(0,0,0) j=1,2,3, \ldots, n$

Here, the distance between $\widetilde{A}=\left(a_{1}, a_{2}, a_{3}\right), \widetilde{B}=\left(a_{1}, a_{2}\right.$ ,$\left.a_{3}\right)$ is presented as:

$d(\widetilde{A}, \widetilde{B})=\sqrt{\frac{1}{3}\left[\left(a_{1}-b_{1}\right)^{2}+\left(a_{2}-b_{2}\right)^{2}+\left(a_{3}-b_{3}\right)^{2}\right]}$

Step 6. Construct the closeness coefficient $\left(C C_{i}\right)$ of each alternative:

$C C_{i}=\frac{d_{i}^{-}}{d_{i}^{*}+d_{i}^{-}}$

where $i=1,2,3, \ldots, m ; d_{i}^{*}$ is a distance from fuzzy positive ideal solution; and $d_{i}$ is the distance from the fuzzy negative ideal solution.

Step 7. Rank and select optimal alternatives.

In the wake of using FTOPSIS steps, we shall get alternatives' rankings in relation to positive ideal and negative ideal solutions.

\section{Results and analysis}

To solve an MCDM problem, the initial and most important step is to convert the problem into a hierarchical structure (Shah et al. 2019a). With the help of FAHP, the structure of studied problem is developed that comprises four levels (goal, criteria, sub-criteria, alternatives) as depicted in Fig. 3. To achieve the goal (first level of hierarchy) of the study, the FAHP is used to get the weights of criteria (second level of hierarchy) and sub-criteria (third level of hierarchy). The obtained weights in second and third levels are used in FTOPSIS to prioritize and rank the alternatives (last level of the hierarchy).

\section{Weights of criteria and sub-criteria}

The weights of main criteria are obtained and presented subsequently in Fig. 4. These weights were obtained by solving the pairwise matrix shown in appendix Table 6 . It can be seen that the experts scored economic factor as more important compared to fiscal and labor factor. The economic criteria obtained $34.12 \%$ weightage followed respectively by fiscal criteria $32.98 \%$, and labor criteria $32.89 \%$.

Later weights of sub-criteria under each main criterion are obtained which are showed in Figure 5. These weights were computed by solving three pairwise matrices given in appendix Tables 7, 8, 9. Table 7 in the Appendix is the pairwise matrix of sub-criteria under labor criterion; Table 8 in the Appendix is the pairwise matrix of sub-criteria under economic criterion; and Table 9 in the Appendix shows the pairwise matrix of sub-criterion under fiscal criterion. It can be seen from the figure that under the labor criterion, the sequence of weights obtained by sub-criteria is L-4>L-1>L-3>L-5>L$2>\mathrm{L}-6>\mathrm{L}-7$. Under the criterion of economic, the sequence obtained is E-4>E-7>E-3>E-5>E-6>E-1 $>$ E-2. Sequence of weights obtained under fiscal criterion is $\mathrm{F}-1>\mathrm{F}-4>\mathrm{F}-5>\mathrm{F}-$ $3>$ F-7 $>$ F-2 $>$ F-6. Proportion of Saudis in the workforce (labor criterion), level of foreign direct investment (economic criterion), and increase non-oil revenue (fiscal criterion) received top weights under their respective criteria mentioned in the brackets.

After obtaining weights of main criteria and sub-criteria under their respective main criteria, we obtained final weights of sub-criteria that are shown in Fig. 6. The final weights are obtained by multiplying weights of sub-criteria with weights of their respective main criterion. For instance, initial weight of L-1 was 0.163 and by multiplying it to 0.329 (weight of labor criterion), we obtained final weight of 0.054 . We can see that the F-1 sub-criteria received the highest final weight of 0.06 which implies that this the most critical factor and should be given priority in the non-oil transition. Conversely, L-7 got the lowest final weight that shows its less importance. The overall ranking of sub-criteria remains as $\mathrm{F}-1>\mathrm{L}-4>(\mathrm{L}-1=\mathrm{E}-$ 4) $>$ E-7 $>$ E-3 $>$ E-5 $>(\mathrm{L}-3=$ F-4 $)>$ E-6 $>(\mathrm{L}-2=\mathrm{L}-5=\mathrm{F}-5)>\mathrm{F}-3>\mathrm{F}-$ $7>\mathrm{F}-2>(\mathrm{L}-6=\mathrm{E}-1=\mathrm{E}-2)>\mathrm{F}-6>\mathrm{L}-7$.

\section{Prioritization of alternatives}

After obtaining the importance of criteria and sub-criteria, we computed and subsequently ranked non-oil sectors based on their performance with respect to their consideration of criteria and sub-criteria. The prioritization is done using FTOPSIS in which weights obtained using FAHP 
Fig. 6 Sub-criteria weights

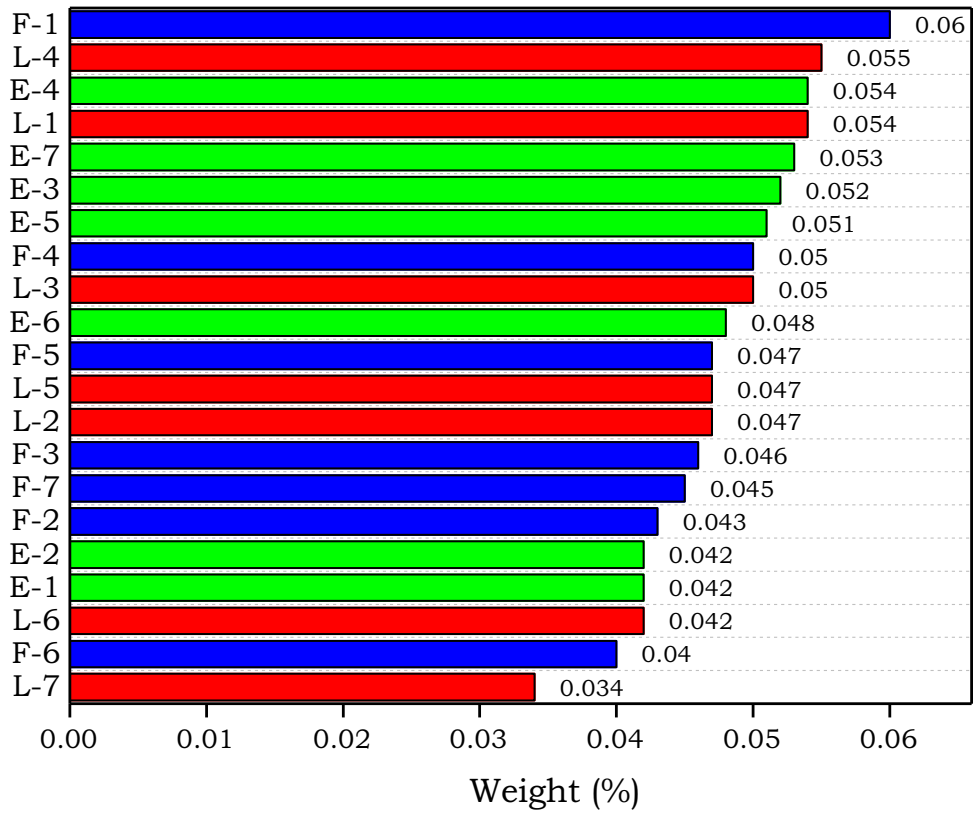

were integrated. Prior to the analysis, sub-criteria were categorized into benefit and cost type criteria. Except L-3 subcriterion, all other sub-criteria were considered as benefit type. Later, fuzzy decision matrix was developed that is given in appendix Table 10. After that, the fuzzy decision matrix was normalized (given in appendix Table 11). By solving the normalized decision matrix using steps given in the "FTOPSIS" section, we obtained the final ranking that is given in Table 5 .

The ranking of the sectors is acquired following the normalized $\boldsymbol{C} \boldsymbol{C}_{\boldsymbol{i}}$ values (the more the better). It can be seen from the Table 4 that the experts ranked Petrochemicals sector on the top as the sector achieved highest $\boldsymbol{C}_{\boldsymbol{i}}$ value of 0.237 . Tourism and Hospitality received second highest $\boldsymbol{C C}_{\boldsymbol{i}}$ of 0.207 and subsequently ranked second in the row. Retail and Wholesale Trade got third place with a $\boldsymbol{C} \boldsymbol{C}_{\boldsymbol{i}}$ score of 0.163 . Manufacturing and Finance sectors achieved fourth and fifth places having $\boldsymbol{C}_{\boldsymbol{i}}$ of 0.155 and 0.117 , respectively. Manufacturing and Finance sectors achieved sixth and seventh places by obtaining $\boldsymbol{C} \boldsymbol{C}_{\boldsymbol{i}}$ of 0.052 and 0.040 , respectively. Healthcare sector is considered least important sector in its contribution to non-oil transition by receiving least $\boldsymbol{C} \boldsymbol{C}_{\boldsymbol{i}}$ of 0.029 .

\section{Discussion}

This study evaluates contribution of eight major non-oil sector in Saudi Arabia's drive towards non-oil economy. To achieve the objective, an integrated framework using two widely used techniques of MCDM are used. These techniques are AHP and TOPSIS. For enhancing the capability of these methods to cope with uncertainty involved in experts' judgment, we integrated fuzzy set theory with AHP and TOPSIS. From the literature survey, three main criteria and twenty-one subcriteria vital for non-oil transition were identified. The selected non-oil sectors were evaluated with respect to these criteria. To achieve the importance of criteria, we employed FAHP. In the process of FAHP, twenty experts from academia and industry were involved.

According to FAHP results, economic criterion achieved highest weight among total three main criteria. Fiscal and labor
Table 5 FTOPSIS results and final ranking

\begin{tabular}{|c|c|c|c|c|c|c|}
\hline Code & Sector & $\mathrm{d}^{+}$ & $\mathrm{d}^{-}$ & $C C_{i}$ & Normalized $C C_{i}$ & Final ranking \\
\hline S-1 & Mining and Metals & 3.3446 & 0.6232 & 0.1571 & 0.040 & 7 \\
\hline S-2 & Tourism and Hospitality & 0.7392 & 3.2244 & 0.8135 & 0.207 & 2 \\
\hline S-3 & Petrochemicals & 0.2715 & 3.718 & 0.9319 & 0.237 & 1 \\
\hline S-4 & Manufacturing & 1.5358 & 2.4011 & 0.6099 & 0.155 & 4 \\
\hline S-5 & Finance & 2.1236 & 1.8086 & 0.4599 & 0.117 & 5 \\
\hline S-6 & Construction & 3.1549 & 0.8006 & 0.2024 & 0.052 & 6 \\
\hline S-7 & Retail and Wholesale Trade & 1.4172 & 2.5202 & 0.6401 & 0.163 & 3 \\
\hline S-8 & Healthcare & 3.5316 & 0.4492 & 0.1128 & 0.029 & 8 \\
\hline
\end{tabular}


criteria received second and third highest weight, respectively. However, the weight difference among three of main criteria is not that substantial to say that the importance of highest weight receiving criterion is much more than the others. Hence, we can say that all these three criteria are considered as vital for achieving the goal. As far as the analysis of sub-criteria, under labor criteria, proportion of Saudis in the workforce achieved highest weight whereas foreign labor received the lowest weight. Level of FDI acquired highest weight in economic criterion while improved infrastructure received lowest weight under the same criterion. Under the fiscal criterion, increase non-oil revenue received highest weight while energy market price reforms received the lowest weight. Overall, the importance of 'increase non-oil revenue' sub-criterion outclasses the importance of rest of twenty sub-criteria.

The FTOPSIS results reveal that the sector S-3 "Petrochemicals" presently contributes more in the kingdom's ultimate goal of developing a non-oil economy. Though the COVID-19 brought substantial hardships for the petrochemical industry in the Saudi Arabia. Amidst the crisis polymers' demand collapsed in major export market. Yet, expert believes it is a potential sector that already have and can trigger the required transition in the future. We took liberty to interview an expert who gave the feedback in favor of the petrochemical sector. The expert underlined that the kingdom has feedstock and raw material for petrochemical industry and it is a key producer of both major "building block petrochemicals and their derivatives." The expert added that the country routinely exports substantial quantity of naphtha and ethylene- two key feedstocks which are considered as enablers for other international petrochemical industries.

\section{Conclusion}

Faced with changes in the global energy market and demographic changes, the Kingdom of Saudi Arabia will no longer be able to grow on the basis of oil revenues and public expenditures, which will lead to a sharp increase in the number of working-age people in Saudi Arabia by 2030. The current labor force participation rate is $41 \%$, and the productivity growth lags behind many emerging economies. The wages of foreign workers who sign temporary contracts are much lower than today's Saudi nationals, accounting for more than half of the labor force. The Kingdom of Saudi Arabia has regarded economic diversification as an important contribution to the establishment of sustainable economic growth. Its decision to lead the diversification of the economy is largely due to its high dependence on oil, and the high dependence of oil on oil shows the risk of volatility under the support of macroeconomic factors in the global market. Last year, the Kingdom's GDP growth slowed due to the plunge in oil production and below average oil prices. Although crude oil is still important to Saudi Arabia, its economic diversification is led by Vision 2030, a reform responsible for large-scale development in specific non-oil sectors to create a post-oil future.

In this study, an analysis of Saudi Arabia's economic diversification, particularly non-oil transition, is conducted. The study establishes a comprehensive model that integrates the Kingdom's economic, labor market, and fiscal perspectives. This study proposes a roadmap based on key factors that can guide Saudi Arabia's future course. Realizing the inherent potential of the non-oil economy requires major reforms in the labor market, business regulations, and fiscal management. After successful implementation, these reforms will bring a new cycle of prosperity to the Kingdom of Saudi Arabia. In addition, the study ranks eight key non-oil sectors with respect to the critical success factors. By doing so, the study presents valuable findings for the government and policymakers to specifically design policies for respective sectors knowing their importance in the transition. Also, the proposed integrated methodology can be useful for other similar studies that involves decision making based on multi criteria or factors.

\section{Appendix}

Table 6 Pairwise matrix of main criteria

\begin{tabular}{llll}
\hline & Labor & Economic & Fiscal \\
\hline Labor & $1,1,1$ & $0.722,0.966,1.311$ & $0.704,0.986,1.413$ \\
Economic & $0.763,1.035,1.385$ & $1,1,1$ & $0.747,1.041,1.476$ \\
Fiscal & $0.708,1.014,1.421$ & $0.678,0.96,1.338$ & $1,1,1$ \\
\hline
\end{tabular}


Table 7 Pairwise matrix of sub-criteria under labor criterion

\begin{tabular}{|c|c|c|c|c|c|c|c|}
\hline & L-1 & L-2 & L-3 & L-4 & L-5 & L-6 & L-7 \\
\hline L-1 & $1,1,1$ & $\begin{array}{l}1.162,1.573 \\
2.056\end{array}$ & $\begin{array}{c}0.879,1.178 \\
1.578\end{array}$ & $\begin{array}{c}0.661,0.871, \\
1.182\end{array}$ & $0.83,1.143,1.531$ & $\begin{array}{l}1.143,1.531 \\
0.811\end{array}$ & $1.531,0.811,1.12$ \\
\hline L-2 & $\begin{array}{c}0.486,0.636 \\
0.861\end{array}$ & $1,1,1$ & $\begin{array}{c}0.785,1.053 \\
1.393\end{array}$ & $\begin{array}{l}0.671,0.886 \\
1.212\end{array}$ & $\begin{array}{c}0.854,1.199 \\
1.647\end{array}$ & $\begin{array}{l}1.199,1.647 \\
0.974\end{array}$ & $\begin{array}{c}1.647,0.974 \\
1.328\end{array}$ \\
\hline L-3 & $\begin{array}{c}0.634,0.849 \\
1.138\end{array}$ & $0.718,0.95,1.274$ & $1,1,1$ & $\begin{array}{c}0.937,1.288, \\
1.692\end{array}$ & $\begin{array}{c}0.606,0.816 \\
1.078\end{array}$ & $\begin{array}{l}0.816,1.078 \\
0.805\end{array}$ & $1.078,0.805,1.1$ \\
\hline L-4 & $\begin{array}{c}0.846,1.148 \\
1.513\end{array}$ & $\begin{array}{c}0.825,1.129 \\
1.489\end{array}$ & $\begin{array}{c}0.591,0.776 \\
1.067\end{array}$ & $1,1,1$ & $1.185,1.595,2.08$ & $1.595,2.08,0.957$ & $2.08,0.957,1.41$ \\
\hline L-5 & $\begin{array}{c}0.653,0.875 \\
1.205\end{array}$ & $\begin{array}{l}0.607,0.834 \\
1.171\end{array}$ & $\begin{array}{c}0.928,1.225 \\
1.651\end{array}$ & $\begin{array}{c}0.481,0.627 \\
0.844\end{array}$ & $1,1,1$ & $1,1,0.914$ & $1,0.914,1.313$ \\
\hline L-6 & $\begin{array}{l}0.653,0.893 \\
1.234\end{array}$ & $\begin{array}{c}0.568,0.753 \\
1.027\end{array}$ & $\begin{array}{c}0.688,0.909 \\
1.242\end{array}$ & $\begin{array}{c}0.494,0.709 \\
1.045\end{array}$ & $\begin{array}{c}0.549,0.762 \\
1.094\end{array}$ & $0.762,1.094,1$ & $1.094,1,1$ \\
\hline L-7 & $0.55,0.737,1.017$ & $\begin{array}{c}0.653,0.858 \\
1.161\end{array}$ & $\begin{array}{l}0.417,0.542 \\
0.738\end{array}$ & $\begin{array}{c}0.498,0.656 \\
0.881\end{array}$ & $\begin{array}{l}0.483,0.651 \\
0.911\end{array}$ & $0.651,0.911,0.48$ & $0.911,0.48,0.658$ \\
\hline
\end{tabular}

Table 8 Pairwise matrix of sub-criteria under economic criterion

\begin{tabular}{|c|c|c|c|c|c|c|c|}
\hline & E-1 & E-2 & E-3 & E-4 & E-5 & E-6 & E-7 \\
\hline E-1 & $1,1,1$ & $\begin{array}{c}0.663,0.851 \\
1.121\end{array}$ & $0.811,1.05,1.38$ & $\begin{array}{c}0.616,0.842 \\
1.125\end{array}$ & $\begin{array}{c}0.619,0.781 \\
1.049\end{array}$ & $\begin{array}{c}0.781,1.049 \\
0.506\end{array}$ & $\begin{array}{c}1.049,0.506 \\
0.699\end{array}$ \\
\hline E-2 & $\begin{array}{c}0.892,1.175 \\
1.509\end{array}$ & $1,1,1$ & $\begin{array}{c}0.439,0.553 \\
0.742\end{array}$ & $\begin{array}{c}0.617,0.783 \\
0.973\end{array}$ & $\begin{array}{c}0.502,0.652 \\
0.869\end{array}$ & $\begin{array}{c}0.652,0.869 \\
0.775\end{array}$ & $\begin{array}{c}0.869,0.775 \\
1.062\end{array}$ \\
\hline E-3 & $\begin{array}{c}0.725,0.952 \\
1.234\end{array}$ & $1.347,1.807,2.28$ & $1,1,1$ & $\begin{array}{c}0.537,0.729 \\
1.041\end{array}$ & $1.06,1.461,1.915$ & $\begin{array}{c}1.461,1.915 \\
1.022\end{array}$ & $\begin{array}{c}1.915,1.022 \\
1.324\end{array}$ \\
\hline E-4 & $\begin{array}{l}0.889,1.188 \\
1.624\end{array}$ & $1.028,1.276,1.62$ & $0.96,1.372,1.86$ & $1,1,1$ & $\begin{array}{c}0.475,0.638 \\
0.854\end{array}$ & $0.638,0.854,0.82$ & $0.854,0.82,1.108$ \\
\hline E-5 & $0.953,1.28,1.615$ & $\begin{array}{c}1.151,1.535 \\
1.991\end{array}$ & $\begin{array}{c}0.522,0.684 \\
0.943\end{array}$ & $\begin{array}{c}1.171,1.567 \\
2.104\end{array}$ & $1,1,1$ & $1,1,0.658$ & $1,0.658,0.966$ \\
\hline E-6 & $1.006,1.43,1.976$ & $\begin{array}{c}0.703,0.942 \\
1.291\end{array}$ & $\begin{array}{c}0.585,0.755 \\
0.979\end{array}$ & $\begin{array}{c}0.703,0.903 \\
1.219\end{array}$ & $0.7,1.035,1.52$ & $1.035,1.52,1$ & $1.52,1,1$ \\
\hline E-7 & $\begin{array}{c}0.831,1.124 \\
1.565\end{array}$ & $\begin{array}{c}0.708,1.013 \\
1.405\end{array}$ & $\begin{array}{c}1.068,1.418 \\
1.871\end{array}$ & $\begin{array}{c}0.523,0.694 \\
0.935\end{array}$ & $\begin{array}{c}1.128,1.463 \\
1.845\end{array}$ & $\begin{array}{c}1.463,1.845 \\
0.867\end{array}$ & $\begin{array}{c}1.845,0.867 \\
1.121\end{array}$ \\
\hline
\end{tabular}

Table 9 Pairwise matrix of sub-criteria under fiscal criterion

\begin{tabular}{|c|c|c|c|c|c|c|c|}
\hline & F-1 & $\mathrm{F}-2$ & F-3 & F-4 & F-5 & F-6 & F-7 \\
\hline F-1 & $1,1,1$ & $\begin{array}{c}1.696,2.127 \\
2.662\end{array}$ & $0.941,1.23,1.763$ & $0.905,1.27,1.719$ & $\begin{array}{c}0.916,1.182 \\
1.542\end{array}$ & $\begin{array}{c}1.182,1.542 \\
1.106\end{array}$ & $\begin{array}{c}1.542,1.106 \\
1.547\end{array}$ \\
\hline F-2 & $0.376,0.47,0.59$ & $1,1,1$ & $\begin{array}{c}0.925,1.145 \\
1.406\end{array}$ & $0.66,0.867,1.216$ & $0.581,0.74,0.936$ & $0.74,0.936,0.865$ & $\begin{array}{c}0.936,0.865 \\
1.167\end{array}$ \\
\hline F-3 & $\begin{array}{c}0.567,0.813 \\
1.063\end{array}$ & $\begin{array}{c}0.711,0.873 \\
1.081\end{array}$ & $1,1,1$ & $0.73,0.935,1.216$ & $\begin{array}{c}0.818,1.063 \\
1.501\end{array}$ & $\begin{array}{c}1.063,1.501 \\
1.273\end{array}$ & $\begin{array}{c}1.501,1.273 \\
1.558\end{array}$ \\
\hline $\mathrm{F}-4$ & $\begin{array}{c}0.582,0.788 \\
1.105\end{array}$ & $\begin{array}{c}0.822,1.153 \\
1.514\end{array}$ & $0.822,1.069,1.37$ & $1,1,1$ & $0.986,1.247,1.66$ & $1.247,1.66,0.814$ & $1.66,0.814,1.189$ \\
\hline F-5 & $\begin{array}{l}0.648,0.846 \\
1.092\end{array}$ & $\begin{array}{l}1.068,1.352 \\
1.721\end{array}$ & $\begin{array}{l}0.666,0.941 \\
1.223\end{array}$ & $\begin{array}{c}0.602,0.802 \\
1.014\end{array}$ & $1,1,1$ & $1,1,0.685$ & $1,0.685,1.003$ \\
\hline F-6 & $\begin{array}{l}0.476,0.646 \\
0.904\end{array}$ & $\begin{array}{l}0.642,0.857 \\
1.155\end{array}$ & $0.52,0.642,0.786$ & $\begin{array}{l}0.603,0.841 \\
1.229\end{array}$ & $0.68,0.997,1.459$ & $0.997,1.459,1$ & $1.459,1,1$ \\
\hline F-7 & $\begin{array}{c}0.889,1.088 \\
1.325\end{array}$ & $\begin{array}{c}0.597,0.776 \\
0.999\end{array}$ & $0.89,1.214,1.551$ & $0.633,0.933,1.38$ & $\begin{array}{c}0.622,0.842 \\
1.137\end{array}$ & $\begin{array}{l}0.842,1.137 \\
0.786\end{array}$ & $1.137,0.786,1$ \\
\hline
\end{tabular}


Table 10 FTOPSIS decision matrix

\begin{tabular}{|c|c|c|c|c|c|c|c|c|}
\hline & S-1 & S-2 & S-3 & S-4 & S-5 & S-6 & S-7 & S-8 \\
\hline L-1 & $4,5,6$ & $5.3,6.3,7.3$ & $5.4,6.4,7.4$ & $4.9,5.9,6.9$ & $4.6,5.6,6.6$ & $4.2,5.2,6.2$ & $4.8,5.8,6.8$ & $3.7,4.7,5.7$ \\
\hline L-2 & $2,3,4$ & $4.3,5.3,6.3$ & $4.5,5.5,6.5$ & $3.2,4.2,5.2$ & $2.9,3.9,4.9$ & $2.2,3.2,4.2$ & $3.5,4.5,5.5$ & $1.9,2.9,3.9$ \\
\hline L-3 & $3.9,4.9,5.9$ & $5.5,6.5,7.5$ & $5.7,6.7,7.7$ & $5.1,6.1,7.1$ & $4.9,5.9,6.9$ & $4.1,5.1,6.1$ & $5.1,6.1,7.1$ & $3.6,4.6,5.6$ \\
\hline L-4 & $2.1,3.1,4.1$ & $4.9,5.9,6.9$ & $5.2,6.2,7.2$ & $3.6,4.6,5.6$ & $3.4,4.4,5.4$ & $2.3,3.3,4.3$ & $4.2,5.2,6.2$ & $2,3,4$ \\
\hline L-5 & $3.3,4.3,5.3$ & $5.8,6.8,7.8$ & $6,7,8$ & $5.6,6.6,7.6$ & $5,6,7$ & $3.7,4.7,5.7$ & $5.2,6.2,7.2$ & $3.2,4.2,5.2$ \\
\hline L-6 & $2.3,3.3,4.3$ & $4.4,5.4,6.4$ & $4.7,5.7,6.7$ & $3.8,4.8,5.8$ & $3.6,4.6,5.6$ & $2.6,3.6,4.6$ & $3.9,4.9,5.9$ & $2.5,3.5,4.5$ \\
\hline L-7 & $2.9,3.9,4.9$ & $4.5,5.5,6.5$ & $5,6,7$ & $4.4,5.4,6.4$ & $4.2,5.2,6.2$ & $3.3,4.3,5.3$ & $4.5,5.5,6.5$ & $3.2,4.2,5.2$ \\
\hline E-1 & $3.9,4.9,5.9$ & $5.1,6.1,7.1$ & $5.6,6.6,7.6$ & $4.8,5.8,6.8$ & $4.6,5.6,6.6$ & $3.8,4.8,5.8$ & $4.6,5.6,6.6$ & $3.8,4.8,5.8$ \\
\hline E-2 & $3.4,4.4,5.4$ & $4.2,5.2,6.2$ & $4.5,5.5,6.5$ & $4.1,5.1,6.1$ & $3.6,4.6,5.6$ & $3.5,4.5,5.5$ & $3.9,4.9,5.9$ & $3.1,4.1,5.1$ \\
\hline E-3 & $2.6,3.6,4.6$ & $3.8,4.8,5.8$ & $4,5,6$ & $3.1,4.1,5.1$ & $3.1,4.1,5.1$ & $2.9,3.9,4.9$ & $3.4,4.4,5.4$ & $2.9,3.9,4.9$ \\
\hline E-4 & $3.1,4.1,5.1$ & $4.9,5.9,6.9$ & $5.3,6.3,7.3$ & $4.1,5.1,6.1$ & $3.5,4.5,5.5$ & $2.4,3.4,4.4$ & $3.9,4.9,5.9$ & $2.6,3.6,4.6$ \\
\hline E-5 & $3.1,4.1,5.1$ & $3.9,4.9,5.9$ & $4.1,5.1,6.1$ & $3.5,4.5,5.5$ & $2.8,3.8,4.8$ & $2.6,3.6,4.6$ & $3.6,4.6,5.6$ & $2.7,3.7,4.7$ \\
\hline E-6 & $2.8,3.8,4.8$ & $4.2,5.2,6.2$ & $5.1,6.1,7.1$ & $3.8,4.8,5.8$ & $3.2,4.2,5.2$ & $3.4,4.4,5.4$ & $4.1,5.1,6.1$ & $2.5,3.5,4.5$ \\
\hline E-7 & $3.7,4.7,5.7$ & $5.8,6.8,7.8$ & $5.9,6.9,7.9$ & $5.6,6.6,7.6$ & $5,6,7$ & $4.4,5.4,6.4$ & $5.6,6.6,7.6$ & $4.3,5.2,6.1$ \\
\hline F-1 & $3.2,4.2,5.2$ & $4.4,5.4,6.4$ & $4.8,5.8,6.8$ & $4,5,6$ & $3.9,4.9,5.9$ & $3.4,4.4,5.4$ & $3.8,4.8,5.8$ & $3.1,4.1,5.1$ \\
\hline $\mathrm{F}-2$ & $3.3,4.3,5.3$ & $4.7,5.7,6.7$ & $4.9,5.9,6.9$ & $4.2,5.2,6.2$ & $4.3,5.3,6.3$ & $3.3,4.3,5.3$ & $4.3,5.3,6.3$ & $3.2,4.2,5.2$ \\
\hline F-3 & $3.1,4.1,5.1$ & $4.2,5.2,6.2$ & $4.4,5.4,6.4$ & $3.9,4.9,5.9$ & $3.5,4.5,5.5$ & $2.8,3.8,4.8$ & $4,5,6$ & $3,4,5$ \\
\hline F-4 & $3.3,4.3,5.3$ & $5,6,7$ & $5.2,6.2,7.2$ & $4.6,5.6,6.6$ & $4.4,5.4,6.4$ & $3.9,4.9,5.9$ & $4.73,5.73,6.73$ & $3.2,4.2,5.2$ \\
\hline F-5 & $3.1,4.1,5.1$ & $5.3,6.3,7.3$ & $5.5,6.5,7.5$ & $4.6,5.6,6.6$ & $4.3,5.3,6.3$ & $3.3,4.3,5.3$ & $5,6,7$ & $3,4,5$ \\
\hline F-6 & $2.8,3.8,4.8$ & $4.8,5.8,6.8$ & $5.1,6.1,7.1$ & $3.7,4.7,5.7$ & $3.6,4.6,5.6$ & $3.1,4.1,5.1$ & $4.6,5.6,6.6$ & $3.1,4.1,5.1$ \\
\hline F-7 & $2.8,3.8,4.8$ & $4.6,5.6,6.6$ & $5.2,6.2,7.2$ & $4.1,5.1,6.1$ & $3.6,4.6,5.6$ & $3,4,5$ & $4,5,6$ & $2.7,3.7,4.7$ \\
\hline
\end{tabular}

Table 11 FTOPSIS normalized decision matrix

\begin{tabular}{|c|c|c|c|c|c|c|c|c|}
\hline & S-1 & S-2 & S-3 & S-4 & S-5 & S-6 & S-7 & S-8 \\
\hline L-1 & $0.54,0.68,0.81$ & $0.72,0.85,0.99$ & $0.73,0.86,1$ & $0.66,0.8,0.93$ & $0.62,0.76,0.89$ & $0.57,0.7,0.84$ & $0.65,0.78,0.92$ & $0.5,0.64,0.77$ \\
\hline L-2 & $0.31,0.46,0.62$ & $0.66,0.82,0.97$ & $0.69,0.85,1$ & $0.49,0.65,0.8$ & $0.45,0.6,0.75$ & $0.34,0.49,0.65$ & $0.54,0.69,0.85$ & $0.29,0.45,0.6$ \\
\hline L-3 & $0.51,0.64,0.77$ & $0.71,0.84,0.97$ & $0.74,0.87,1$ & $0.66,0.79,0.92$ & $0.64,0.77,0.9$ & $0.53,0.66,0.79$ & $0.66,0.79,0.92$ & $0.47,0.6,0.73$ \\
\hline L-4 & $0.29,0.43,0.57$ & $0.68,0.82,0.96$ & $0.72,0.86,1$ & $0.5,0.64,0.78$ & $0.47,0.61,0.75$ & $0.32,0.46,0.6$ & $0.58,0.72,0.86$ & $0.28,0.42,0.56$ \\
\hline L-5 & $0.41,0.54,0.66$ & $0.73,0.85,0.98$ & $0.75,0.88,1$ & $0.7,0.83,0.95$ & $0.63,0.75,0.88$ & $0.46,0.59,0.71$ & $0.65,0.78,0.9$ & $0.4,0.53,0.65$ \\
\hline L-6 & $0.34,0.49,0.64$ & $0.66,0.81,0.96$ & $0.7,0.85,1$ & $0.57,0.72,0.87$ & $0.54,0.69,0.84$ & $0.39,0.54,0.69$ & $0.58,0.73,0.88$ & $0.37,0.52,0.67$ \\
\hline L-7 & $0.41,0.56,0.7$ & $0.64,0.79,0.93$ & $0.71,0.86,1$ & $0.63,0.77,0.91$ & $0.6,0.74,0.89$ & $0.47,0.61,0.76$ & $0.64,0.79,0.93$ & $0.46,0.6,0.74$ \\
\hline E-1 & $0.51,0.64,0.78$ & $0.67,0.8,0.93$ & $0.74,0.87,1$ & $0.63,0.76,0.89$ & $0.61,0.74,0.87$ & $0.5,0.63,0.76$ & $0.61,0.74,0.87$ & $0.5,0.63,0.76$ \\
\hline E-2 & $0.52,0.68,0.83$ & $0.65,0.8,0.95$ & $0.69,0.85,1$ & $0.63,0.78,0.94$ & $0.55,0.71,0.86$ & $0.54,0.69,0.85$ & $0.6,0.75,0.91$ & $0.48,0.63,0.78$ \\
\hline E-3 & $0.43,0.6,0.77$ & $0.63,0.8,0.97$ & $0.67,0.83,1$ & $0.52,0.68,0.85$ & $0.52,0.68,0.85$ & $0.48,0.65,0.82$ & $0.57,0.73,0.9$ & $0.48,0.65,0.82$ \\
\hline E-4 & $0.42,0.56,0.7$ & $0.67,0.81,0.95$ & $0.73,0.86,1$ & $0.56,0.7,0.84$ & $0.48,0.62,0.75$ & $0.33,0.47,0.6$ & $0.53,0.67,0.81$ & $0.36,0.49,0.63$ \\
\hline E-5 & $0.51,0.67,0.84$ & $0.64,0.8,0.97$ & $0.67,0.84,1$ & $0.57,0.74,0.9$ & $0.46,0.62,0.79$ & $0.43,0.59,0.75$ & $0.59,0.75,0.92$ & $0.44,0.61,0.77$ \\
\hline E-6 & $0.39,0.54,0.68$ & $0.59,0.73,0.87$ & $0.72,0.86,1$ & $0.54,0.68,0.82$ & $0.45,0.59,0.73$ & $0.48,0.62,0.76$ & $0.58,0.72,0.86$ & $0.35,0.49,0.63$ \\
\hline E-7 & $0.47,0.59,0.72$ & $0.73,0.86,0.99$ & $0.75,0.87,1$ & $0.71,0.84,0.96$ & $0.63,0.76,0.89$ & $0.56,0.68,0.81$ & $0.71,0.84,0.96$ & $0.54,0.66,0.77$ \\
\hline F-1 & $0.47,0.62,0.76$ & $0.65,0.79,0.94$ & $0.71,0.85,1$ & $0.59,0.74,0.88$ & $0.57,0.72,0.87$ & $0.5,0.65,0.79$ & $0.56,0.71,0.85$ & $0.46,0.6,0.75$ \\
\hline F-2 & $0.48,0.62,0.77$ & $0.68,0.83,0.97$ & $0.71,0.86,1$ & $0.61,0.75,0.9$ & $0.62,0.77,0.91$ & $0.48,0.62,0.77$ & $0.62,0.77,0.91$ & $0.46,0.61,0.75$ \\
\hline F-3 & $0.48,0.64,0.8$ & $0.66,0.81,0.97$ & $0.69,0.84,1$ & $0.61,0.77,0.92$ & $0.55,0.7,0.86$ & $0.44,0.59,0.75$ & $0.63,0.78,0.94$ & $0.47,0.63,0.78$ \\
\hline F-4 & $0.46,0.6,0.74$ & $0.69,0.83,0.97$ & $0.72,0.86,1$ & $0.64,0.78,0.92$ & $0.61,0.75,0.89$ & $0.54,0.68,0.82$ & $0.66,0.8,0.93$ & $0.44,0.58,0.72$ \\
\hline F-5 & $0.41,0.55,0.68$ & $0.71,0.84,0.97$ & $0.73,0.87,1$ & $0.61,0.75,0.88$ & $0.57,0.71,0.84$ & $0.44,0.57,0.71$ & $0.67,0.8,0.93$ & $0.4,0.53,0.67$ \\
\hline F-6 & $0.39,0.54,0.68$ & $0.68,0.82,0.96$ & $0.72,0.86,1$ & $0.52,0.66,0.8$ & $0.51,0.65,0.79$ & $0.44,0.58,0.72$ & $0.65,0.79,0.93$ & $0.44,0.58,0.72$ \\
\hline F-7 & $0.39,0.53,0.67$ & $0.64,0.78,0.92$ & $0.72,0.86,1$ & $0.57,0.71,0.85$ & $0.5,0.64,0.78$ & $0.42,0.56,0.69$ & $0.56,0.69,0.83$ & $0.38,0.51,0.65$ \\
\hline
\end{tabular}


Author contribution All authors have contributed to the study. Alshehrei Abdulrahman Mohammed N developed the contextual framework of the study and prepared the original draft. Syed Ahsan Ali Shah developed methodology and analyzed the data. Geng Xianhui supervised, reviewed and improved the initial version of the manuscript.

Data availability The datasets used and/or analyzed during the current study are available from the corresponding author on reasonable request.

\section{Declarations}

Ethics approval and consent to participate Not applicable

Consent for publication Not applicable

Competing interests The authors declare no competing interests.

\section{References}

Ahmad M, Chandio AA, Solangi YA, Shah SAA, Shahzad F, Rehman A, Jabeen G (2020a) Dynamic interactive links among sustainable energy investment, air pollution, and sustainable development in regional China. Environ Sci Pollut Res 28:1502-1518. https://doi.org/ 10.1007/s11356-020-10239-8

Ahmad M, Rehman A, Shah SAA, Solangi YA, Chandio AA, Jabeen G (2020b) Stylized heterogeneous dynamic links among healthcare expenditures, land urbanization, and $\mathrm{CO} 2$ emissions across economic development levels. Sci Total Environ 753:142228. https://doi. org/10.1016/j.scitotenv.2020.142228

Alam F (2009) A study of economic diversification in Saudi Arabia since 1970

Al-Asfour A, Khan SA (2014) Workforce localization in the Kingdom of Saudi Arabia: issues and challenges. Hum Resour Dev Int 17:243253

Alawi S (2019) Relationship between capital requirement, ownership structure, and financial performance in Saudi Arabian listed companies. Asian Econ Financ Rev 9:1077-1090

Albassam BA (2015) Economic diversification in Saudi Arabia: Myth or reality? Res Policy 44:112-117

Aldubyan M, Gasim A (2020) Energy price reform in Saudi Arabia: Modeling the economic and environmental impacts and understanding the demand response. Energy Policy 148:111941

Alhamad HS (2014) The labor market in Saudi Arabia: Foreign workers, unemployment, and minimum wage. Inq J 6

Alkhathlan KA, Alkhateeb TTY, Mahmood H, Bindabel WA (2020) Concentration of oil sector or diversification in Saudi economy: consequences on growth sustainability. Entrep Sustain Issues 7: 3369-3384

Al-Qudair KHA (2005) The relationship between government expenditure and revenues in the Kingdom of Saudi Arabia: Testing for cointegration and causality. Econ Adm 19:

Al-Sarihi A (2019) Climate Change and Economic Diversification in Saudi Arabia: Integrity, Challenges, and Opportunities

Banafea W, Ibnrubbian A (2018) Assessment of economic diversification in Saudi Arabia through nine development plans. OPEC Energy Rev 42:42-54

Belloumi M, Alshehry A (2018) The impacts of domestic and foreign direct investments on economic growth in Saudi Arabia. Economies $6: 18$

Biygautane M, Hodge G, Gerber P (2018) The Prospect of Infrastructure Public-Private Partnerships in Kuwait, Saudi Arabia, and Qatar:
Transforming Challenges into Opportunities. Thunderbird Int Bus Rev 60:329-346

Bokhari AAH (2017) Economic Diversification in Saudi Arabia: Looking beyond Oil. Int J Sci Commer Humanit 5:1-12

Bokhari AAH (2020) The Twinning of Inflation and Unemployment Phenomena in Saudi Arabia: Phillips Curve Perspective. Contemp Econ 14:254-272

Callen MT, Cherif R, Hasanov F, et al (2014) Economic diversification in the GCC: Past, present, and future. International Monetary Fund

Chen Y, Zheng W, Li W, Huang Y (2021) Large group Activity security risk assessment and risk early warning based on random forest algorithm. Pattern Recogn Lett 144:1-5

El-Awady S, Al-Mushayqih S, Al-Oudah E (2020) An analytical study of the determinants of foreign investment in Saudi Arabia" Saudi Vision 2030. In: CBER-MEC 9th International Conference on Business \& Economic Development (ICBED)-A Virtual Conference. $\mathrm{p} 9$

Emara N, Zhang X, Liu S (2019) Economic Growth and Financial Stability in MENA Countries: Does Exporting Oil Matters?

Forman E, Peniwati K (1998) Aggregating individual judgments and priorities with the analytic hierarchy process. Eur J Oper Res 108: 165-169

Han H, Trimi S (2018) A fuzzy TOPSIS method for performance evaluation of reverse logistics in social commerce platforms. Expert Syst Appl 103:133-145. https://doi.org/10.1016/j.eswa.2018.03.003

He L, Chen Y, Zhao H, Tian P, Xue Y, Chen L (2018a) Game-based analysis of energy-water nexus for identifying environmental impacts during Shale gas operations under stochastic input. Sci Total Environ 627:1585-1601

He L, Shen J, Zhang Y (2018b) Ecological vulnerability assessment for ecological conservation and environmental management. J Environ Manag 206:1115-1125

He L, Shao F, Ren L (2020) Sustainability appraisal of desired contaminated groundwater remediation strategies: an information-entropybased stochastic multi-criteria preference model. Environ Dev Sustain 1-21

Hussain I, Rehman A (2021) Exploring the dynamic interaction of CO2 emission on population growth, foreign investment, and renewable energy by employing ARDL bounds testing approach. Environ Sci Pollut Res:1-11

Iradian G (2019) Saudi Arabia: Fiscal Consolidation Resumes

Jiskani IM, Shah SAA, Qingxiang C, Zhou W, Lu X (2020) A multicriteria based SWOT analysis of sustainable planning for mining and mineral industry in Pakistan. Arab J Geosci 13: https://doi.org/ 10.1007/s12517-020-06090-3

Jiskani IM, Cai Q, Zhou W, Ali Shah SA (2021) Green and climate-smart mining: A framework to analyze open-pit mines for cleaner mineral production. Res Policy 71:102007. https://doi.org/10.1016/j. resourpol.2021.102007

Khojah M (2018) Corporate Narrative Disclosures in Saudi Arabia

Lai Y-J, Liu T-Y, Hwang C-L (1994) Topsis for MODM. Eur J Oper Res 76:486-500

Madhi ST, Barrientos A (2003) Saudisation and employment in Saudi Arabia. Career Dev Int

Mahroum S, Al-Saleh Y (2016) Economic diversification policies in natural resource rich economies. Routledge

Moshashai D, Leber AM, Savage JD (2020) Saudi Arabia plans for its economic future: Vision 2030, the National Transformation Plan and Saudi fiscal reform. Br J Middle East Stud 47:381-401

Muhammad N, Fang Z, Shah SAA, Akbar MA, Alsanad A, Gumaei A, Solangi YA (2020) A Hybrid Multi-Criteria Approach for Evaluation and Selection of Sustainable Suppliers in the Avionics Industry of Pakistan. Sustainability 12:4744

Musaad OAS, Zhuo Z, Siyal ZA et al (2020a) An Integrated MultiCriteria Decision Support Framework for the Selection of Suppliers in Small and Medium Enterprises based on Green 
Innovation Ability. Processes 8:418. https://doi.org/10.3390/ pr8040418

Musaad O, Sultan A, Zhuo Z et al (2020b) A Fuzzy Multi-Criteria Analysis of Barriers and Policy Strategies for Small and Medium Enterprises to Adopt Green Innovation. Symmetry (Basel) 12:116

Park Y-E, Allui A, AlSelaimi R (2019) Determinants of entry modes choice for MNEs: Exploring major challenges and implications for Saudi Arabia. In: Creative Business and Social Innovations for a Sustainable Future. Springer, pp 107-115

Ramady MA (2010) The Saudi Arabian economy: Policies, achievements, and challenges. Springer Science \& Business Media

Rehman A, Rauf A, Ahmad M, Chandio AA, Deyuan Z (2019) The effect of carbon dioxide emission and the consumption of electrical energy, fossil fuel energy, and renewable energy, on economic performance: evidence from Pakistan. Environ Sci Pollut Res 26:21760 21773

Shah SAA (2019) Feasibility study of renewable energy sources for developing the hydrogen economy in Pakistan. Int J Hydrogen Energy

Shah SAA, Longsheng C (2020) New environmental performance index for measuring sector-wise environmental performance: a case study of major economic sectors in Pakistan. Environ Sci Pollut Res:1-16

Shah SAA, Solangi YA (2019) A sustainable solution for electricity crisis in Pakistan: opportunities, barriers, and policy implications for 100\% renewable energy. Environ Sci Pollut Res 26:29687-29703. https://doi.org/10.1007/s11356-019-06102-0

Shah SAA, Solangi YA, Ikram M (2019a) Analysis of barriers to the adoption of cleaner energy technologies in Pakistan using Modified Delphi and Fuzzy Analytical Hierarchy Process. J Clean Prod 235:1037-1050. https://doi.org/10.1016/j.jclepro.2019.07.020

Shah SAA, Zhou P, Walasai GD, Mohsin M (2019b) Energy security and environmental sustainability index of South Asian countries: A composite index approach. Ecol Indic 106:105507. https://doi.org/ 10.1016/j.ecolind.2019.105507

Shah SAA, Longsheng C, Solangi YA et al (2021) Energy trilemma based prioritization of waste-to-energy technologies: implications for post-COVID-19 green economic recovery in Pakistan. J Clean Prod 284:124729

Snudden S (2019) Labor and behavior determinants of remittances in Saudi Arabia. Econ Notes Rev Banking, Financ Monet Econ 48: e12145

Sohail MS (2012) Economic diversification in Saudi Arabia: The need for improving competitiveness for sustainable development. In: The GCC Economies. Springer, pp 147-156
Solangi YA, Longsheng C, Shah SAA (2021) Assessing and Overcoming the Renewable Energy Barriers for Sustainable Development in Pakistan: An Integrated AHP and Fuzzy TOPSIS Approach. Renew Energy

Thompson KA, Al-Aujan DT, Al-Nazha R et al (2012) Saudi Arabia's economic diversification: A case study in entrepreneurship. J Manag Bus Res 2:37-40

Topal A (2019) Economic reforms and women's empowerment in Saudi Arabia. In: Women's Studies International Forum. Elsevier, $p$ 102253

Trigunarsyah B, Santoso T, Hassanain M, Tuffaha F (2019) Enabling Factors for Adopting Industrial Building System into the Kingdom of Saudi Arabia. In: CIB World Building Congress 2019. The Hong Kong Polytechnic University, pp 1-9

Varshney D (2019) The Strides of the Saudi Female Workforce: Overcoming Constraints and Contradictions in Transition. J Int Womens Stud 20:359-372

Vietor RHK, Sheldahl-Thomason H (2018) Saudi Arabia: Vision 2030

Xu L, Shah SAA, Zameer H, Solangi YA (2019a) Evaluating renewable energy sources for implementing the hydrogen economy in Pakistan: a two-stage fuzzy MCDM approach. Environ Sci Pollut Res 26:33202-33215. https://doi.org/10.1007/s11356-019-06431-0

$\mathrm{Xu}$ L, Wang Y, Shah SAA et al (2019b) Economic Viability and Environmental Efficiency Analysis of Hydrogen Production Processes for the Decarbonization of Energy Systems. Processes 7: 494

Younis I, Naz A, Shah SAA et al (2021) Impact of stock market, renewable energy consumption and urbanization on environmental degradation: new evidence from BRICS countries. Environ Sci Pollut Res:1-17

Zadeh LA (1978) Fuzzy sets as a basis for a theory of possibility. Fuzzy Sets Syst 1:3-28

Zhu B, Ma S, Xie R, Chevallier J, Wei YM (2018) Hilbert spectra and empirical mode decomposition: A multiscale event analysis method to detect the impact of economic crises on the European carbon market. Comput Econ 52:105-121

Zuo C, Chen Q, Tian L, Waller L, Asundi A (2015) Transport of intensity phase retrieval and computational imaging for partially coherent fields: The phase space perspective. Opt Lasers Eng 71:20-32

Publisher's note Springer Nature remains neutral with regard to jurisdictional claims in published maps and institutional affiliations. 